Niğde Ömer Halisdemir Üniversitesi Mühendislik Bilimleri Dergisi
Niğde Ömer Halisdemir University Journal of Engineering Sciences

\title{
Çelik basınç çubuklarında bazı güçlendirme türlerinin basınç dayanımı kapasitelerine katkısının deneysel araştırılması
}

\author{
Experimental investigation of contribution of some strengthening types to \\ compressive strength capacities in steel braces
}

\author{
Oğuz Düğenci ${ }^{1}$ ** (iD \\ ${ }^{1}$ Erciyes Üniversitesi, Mühendislik Fakültesi, İnşaat Mühendisliği Bölümü, 38039, Kayseri, Türkiye
}

\begin{abstract}
Özet
Eksenel basınç etkisindeki çelik elemanlar burkulma olmayacak şekilde tasarlanır. Ancak yapının kullanım amacının değişmesi veya performans hesapları sonrasında yapının istenilen dayanımları sağlamadığı durumlarda güçlendirilmesi gerekebilir. Bu çalıșmada, belirli narin enkesite sahip basınç çubuğu referans alınarak, çubuğun zayıf eksen ataletinin artırılmasına yönelik dört farklı güçlendirme uygulanmıştır. Bunlardan üçü çelik plaka ilavesi, dördüncüsü CFRP sarg1 yapılmasıdır. Çelik güçlendirmelerin biri kaynaklı diğer ikisi ise bulon destekli güçlendirmedir. Güçlendirilmiş test numuneleri hazırlanan bir düzenekte, yarı statik tersinir tekrarlı eksenel kuvvete maruz bırakılmıștır. Test sonucunda eksenel kuvvetboyuna deformasyon eğrileri elde edilmiştir. Elde edilen verilerle taşıma kapasiteleri, yer değiştirme kapasiteleri, burkulma yükleri, enerji yutma kapasiteleri ile süneklik parametreleri karşılaştırmalı olarak ortaya konulmuştur. Deneyler sonucunda ek levhaların gövde boyunca kaynaklanmasıyla güçlendirilen kaynaklı numunenin, burkulma dayanımında en büyük artışı gösterdiği, ancak çekmede daha erken göçtüğü görülmüştür. Diğer numunelerin basınç dayanımına katkısının düşük seviyelerde kaldığı görülmüş olup, buna karşılık yapılacak iyileştirmelerle daha iyi performansa ulaşılabileceği sonucuna ulaşıılmıştır.
\end{abstract}

Anahtar kelimeler: Çelik basınç çubuğu, Çelik eleman güçlendirme, Burkulma dayanımın artırılması, Enerji yutma kapasitesi, Histeresis eğrisi, Enerji sünekliği,

\section{Giriş}

Basınca maruz elemanlarda yapısal beklenti, üzerlerine gelen eksenel basınç kuvvetini burkulmadan bir sonraki taşıyıcı elemana veya mesnete iletebilmesidir. Bu durumda yapısal güvenlik basınç çubukları için sağlanmış olmaktadır. Basınç çubukları çelik yapılarda deprem perdeleri olarak görev yapan çapraz elemanlar ve kafes sistemlerdeki basınca çalışan elemanlardır (Şekil 1).

Bir basınç çubuğunun eksenel basınç kuvveti taşıma seviyesi, projelendirmesi sonucunda ortaya konulur. Çubuğun sahip olacağı bu basınç kapasitesi seviyesi, sadece tek hadde profillerin kullanılmasıyla belirli mertebelere

\begin{abstract}
Steel members under the effect of axial compression are designed in such a way that there is no buckling. However, these elements should be strengthened in cases where the purpose of use of the structure changes or the building performance does not provide the desired strengths. In this study, four different strengthening were applied to increase the weak moment of inertia of the members by reference to the braces with a certain slender cross-section. Three of them are steel plate addition and the fourth is CFRP wrapping. One of the steel strengthening is welded and the other two are bolt supported strengthening. Strengthened test specimens were subjected to quasi-static cyclical axial loading with a prepared setup. As a consequence of the test, axial force-axial deformation curves were obtained. With the obtained data, bearing capacities, displacement capacities, buckling loads, energy dissipation capacities and ductility parameters are presented comparatively. As a result of the experiments, it was seen that the sample strengthened by welding the additional plate along the body caused the greatest increase in buckling strength compared to the reference sample, but it caused earlier failure in tensile. It was concluded that the contribution of the other samples to the compressive strength remained at low levels, but better performance could be achieved with improvements.
\end{abstract}

Keywords: Steel braces, Strengthening of steel members, Buckling strength, energy dissipation capacity, Hysteresis curve, Energy ductility

kadar sağlanabilir. Çok fazla eksenel basınç kuvvetinin etkimesi durumunda, çubuklara ilave sargı yapılması veya basınç çubuklarının burkulması önlenmiş basınç çubuğu (buckling restrained braced-BRB) [1-5] biçimde tasarlanması gerekir. Böylelikle çubuk, çekme ve basınç etkisinde burkulmadan ve sünek davranışla etkiyen yükleri karşılayabilecektir. BRB ile ilgili çalışmalar, ilk olarak 1970'li yılların başında başlamıştır [6-8]. Farklı kesit ve sarg1 çeşitleriyle hala davranışın iyileştirilmesi yönünde çalışmalar devam etmektedir.

BRB kesitleri, çelik yapı projesindeki gereksinime bağ $\mathrm{l}_{1}$ olarak, yapının üretimi öncesinde tasarlanır ve atölye ortamında üretilebilir. Ancak üretimi gerçekleștirilmiş bazı

\footnotetext{
* Sorumlu yazar / Corresponding author, e-posta / e-mail: dugenci@ erciyes.edu.tr (O. Düğenci)

Geliș / Recieved: 03.09.2021 Kabul/ Accepted: 17.11.2021 Yayımlanma/Published: 14.01.2022

doi: 10.28948/ngmuh.990509
} 
yapılarda kullanım amacındaki değişiklik ve sonradan ilave yüklere maruz kalınması vb. durumlarda, taşıyıcı elemanların taşıma kapasitelerinin artırılması gerekebilir. Kullanım amacındaki değişikliklerde önceki yönetmeliklerde olduğu gibi TÇYY-2016 [9] ve TBDY 2018 [10] 'e göre ve diğer Eurocode 3 (TS EN 1993-1-1) [11, 12] ve ANSI/AISC 360-16 [13] gibi yabanc1 standart ve şartnamelere göre de sistemin sismik performansının artırılması için önerilen yöntemler ile hem sistem bazında hem de eleman bazında güçlendirilmesi önerilmektedir. Özellikle basınca çalışan elemanların güçlendirilmesinde, burkulmanın önlenebilmesi için elemanın BRB'nin tasarımına benzer dış sargılarla sarılarak güçlendirilmesi sağlanmalıdır.

Taşıyıcı sistem malzemesine göre güçlendirmeler farklılıklar gösterir. Malzeme özelliğine ve birleștirme vasıtalarının birleşimde gösterdiği kolaylığa bağlı olarak çelik sistem güçlendirmeleri, betonarme sistemlere göre daha kolaydır. Betonarme sistemlerin çelik elemanlar ve sistemler ile güçlendirilmesi de yaygın kullanılan bir yöntemdir ve yönetmeliğimiz kapsamında önerilmektedir [14]. Genellikle geleneksel çelik yapı elemanı güçlendirme yöntemleri, çoğu zaman yapısal elemanını söküp değiştirmek veya dışardan (sarg1 veya kaynaklı) çelik plaka veya profil ilave edilmesiyle gerçekleştirilir [15]. Bu yöntem sırasıyla, kaynak veya cıvatalı bağlantı onarım işleri, daha fazla yorulma sorunu ve uzun montaj süresi nedeniyle uygun bir çözüm olamayabilir [16]. Bununla birlikte kesit kayıpları veya malzemede gevrekleşme gerçekleşebileceği gibi, kesite profil ve plaka ilavesi ağır kaldırma ekipmanları gerektirir ve yapıya daha fazla ölü yük ekler. Eklenen çelik plakalarında korozyona karşı hassaslığı dikkate alınmalı ve bunun gelecekteki bakımlarda maliyetlerin artmasına neden olabileceği düşünülmelidir $[16,17]$. Çoğu durumda, kaynaklarla ilgili yorulma sorunları nedeniyle kaynak, istenen bir çözüm değildir [18]. Bu gibi geleneksel yöntemlerin yanı sıra fiber takviyeli polimer (FRP) ile sargılı güçlendirme çalışmaları da yapılmaktadır [3, 16, 17, 19]. Hem burkulması önlenmiş basınç çubukları hem de diğer sarg1 çalışmalarında amaç, çelik elemanların çekmede gösterdiği performansı basınç altında da gösterebilmesini sağlamaktır (Şekil 1.)
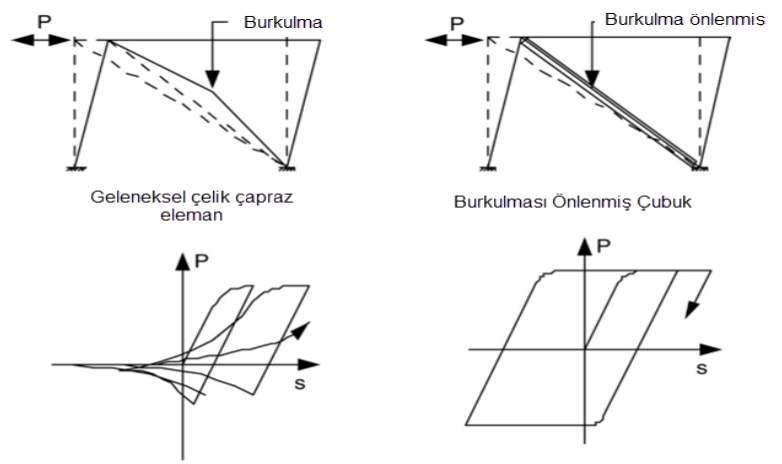

Şekil 1. Geleneksel basınç çubuğu ile burkulması engellenmiş basınç çubuğunun eksenel kuvvet-deplasman ilişkisi $[2,20,21]$
Literatürdeki bütün sarg1 ve kesitin büyütülmesi çalışmaları, basınç altında burkulma dayanımının artırılmasına yöneliktir. Mevcut üretimi yapılmış basınç elemanlarının basınç kapasiteleri, burkulma dayanımının artırılması esasına göre yapılmaktadır (Şekil 2).

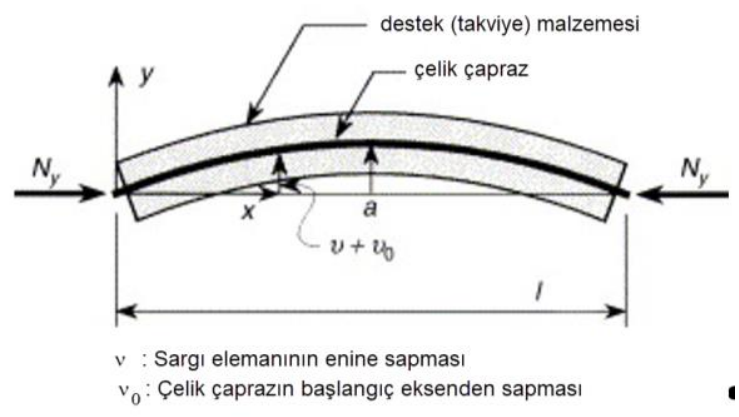

Şekil 2. Sargılı çelik çaprazın şekil değiştirme durumu $[2,20]$

Kesit ortasında yanal yer değiştirmenin önlenmesi, burkulmanın önlenmesi anlamına gelir. Ancak eksenel yükü bünyesinde barındıran esas basınç çubuğunun (çekirdek eleman) başlangıçta sargı profiline veya sargı sistemine (çelik tüp ve beton sargı) yaslanması için gerekli bir boşluk bulunmalıdır. Bu boşluk enkesitin akma sınırını geçmeyecek şekilde çubuk ortasının bir başlangıç sapması (yer değiştirmesi) $\left(v_{0}\right)$ yapacak nitelikte olmalıdır. Eksenel kuvvetin artışına bağlı bu başlangıç sapması sargı elemanının da desteğiyle birlikte tüm sistemin enine yer değiştirmesinin ( $v)$ artışına sebep olur [2, 22].

Bir sistemin güçlendirilmesinde bir nevi sönümleyici niteliğinde olan BRB'lerin sonradan yapıya ilavesiyle güçlendirme elemanı olarak kullanılması mümkündür. Bir yapının çelik perdelerle güçlendirilmesi gerektiğinde bu elemanlar rahatlıkla kullanılabilir. Ancak eleman bazında güçlendirme yapılması gerektiğinde, montajı tamamlanmış ve kullanılmakta olan bir çelik basınç çubuğunun, burkulması önlemiş basınç çubuğuna dönüştürülmesi zordur. $\mathrm{Bu}$ zorluk üretimdeki zorluğun yanı sıra, kesitin beton dolu ağırlığının sisteme ilave yük şeklinde etkimesi gibi bir olumsuzluğu da yanında getirmektedir. Özellikle çatı kafes kirişlerinde bu durum daha da güç bir hal almaktadır. Bu bağlamda bahsedilen türdeki elemanların güçlendirilmesi çalışmanın temelini oluşturmaktadır.

$\mathrm{Bu}$ çalışma, mevcut basınca çalışan çelik elemanların, çelik levha ve karbon elyaf takviyesiyle güçlendirilmesini esas alarak eksenel basınç dayanımı kapasitelerinin artırılmasını amaçlamaktadır. Bu kapsamda üretimi tamamlanmış basınç çubuklarının (özellikle kafes kirişlerdeki) güçlendirilmesi düşünülerek, farklı güçlendirme teknikleri aynı kesit ve malzeme üzerinde denenmiştir. Güçlendirme uygulaması CFRP sarg1, levha kaynaklanması ve iki farklı geometride bulonlu levha ilavesi olarak dört farklı şekildedir. Bütün test numuneleri tersinir tekrarlı eksenel yükleme maruz bırakılmıştır. Deney verileri, test düzeneğinde kullanılan yük hücresi ve yer değiştirme ölçerler yardımıyla elde edilmiştir. Elde edilen verilerle yapısal elemanın karakteristik burkulma kapasiteleri, 
süneklikleri ve enerji tüketim kapasiteleri ortaya konulmuş ve birbirleriyle karşılaştırılmıştır.

\section{Materyal ve metot}

\subsection{Test numuneleri}

Deneylerde referans basınç çubuğuyla birlikte toplam beş adet numune test edilmiştir. Bütün deney numuneleri (güçlendirilen esas çubuk) 10 mm kalınlığında aynı levhadan plazma yardımıyla kesilen parçalardan teşkil edilmiştir. Referans basınç çubuğu ile çelik güçlendirme levhaları aynı malzemedir. Referans numunesinin ortası dikdörtgen formda ve $65 \times 10 \mathrm{~mm}$ enkesitlidir. Başlık bölgeleri, orta bölgesine göre daha geniş enkesitli $(85 \times 10 \mathrm{~mm})$ olup aynı zamanda hem rijitlik kazandırmak hem de deney düzeneğine artı şeklindeki kanala bağlantı sağlaması amacıyla $410 \times 35 \times 10$ mm ölçülerinde iki adet levha kaynatılarak artı en kesit formuna getirilmiştir. Uygulanan kaynak kalınlığı 4 mm'dir. $\mathrm{Bu}$ ölçülerdeki profil, bütün test numuneleri için esas çubuk niteliğindedir ve güçlendirmeler bu kesite yapılmıştır. Numunelerin isimlendirmeleri ve açıklamaları Tablo 1'de, numune ölçü ve görünümleri ise Şekil 3 ve Şekil 4'de verilmiştir.

Tablo 1. Numune adlandırması ve açıklamalar

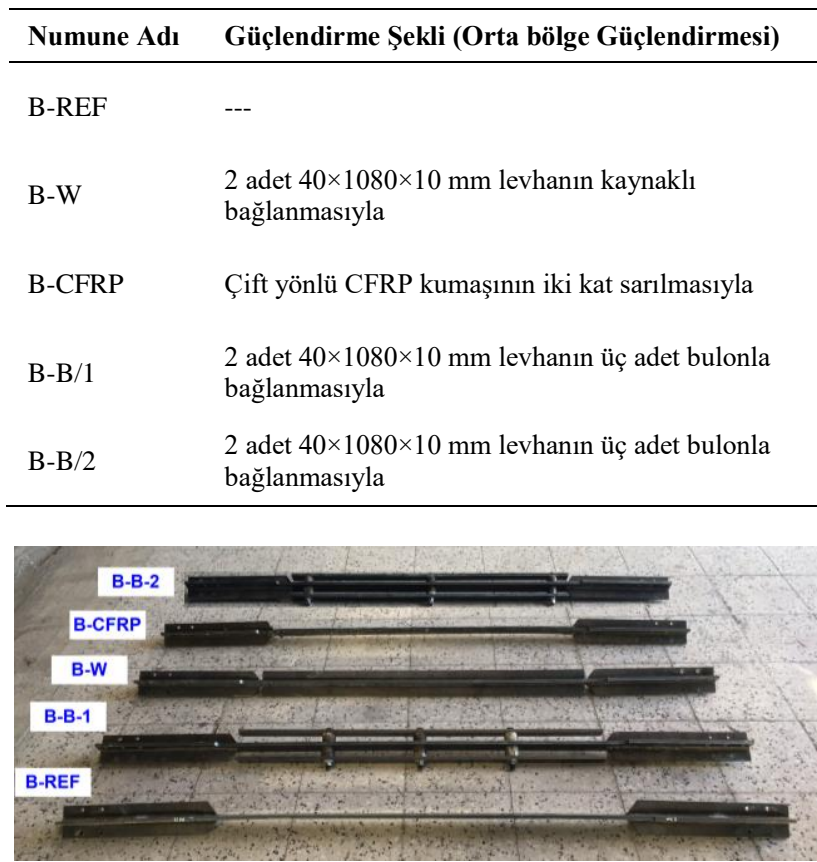

Şekil 3. Test numunelerinin deney öncesi görünümleri

\subsection{Malzeme özellikleri}

\subsection{1. Çelik malzemesi}

Deneylerde kullanılan çelik malzemelerinin tamamı (esas basınç çubuğu ve güçlendirme levhaları) $10 \mathrm{~mm}$ kalınlığında çelik levhadan kesilerek oluşturulmuştur. $\mathrm{Bu}$ levhadan yine TS EN ISO 6892-1'e [20] göre çekme numuneleri uygun boy ve gerilme yığılması oluşmayacak şekilde eğrisel çapla inceltilerek hazırlanmıştır ( $b k z$. Şekil 5.). Kalibrasyonlu çekme cihazında çekme testine tabi tutulan malzemelerin mekanik özellikleri Tablo 2'de verilmektedir.

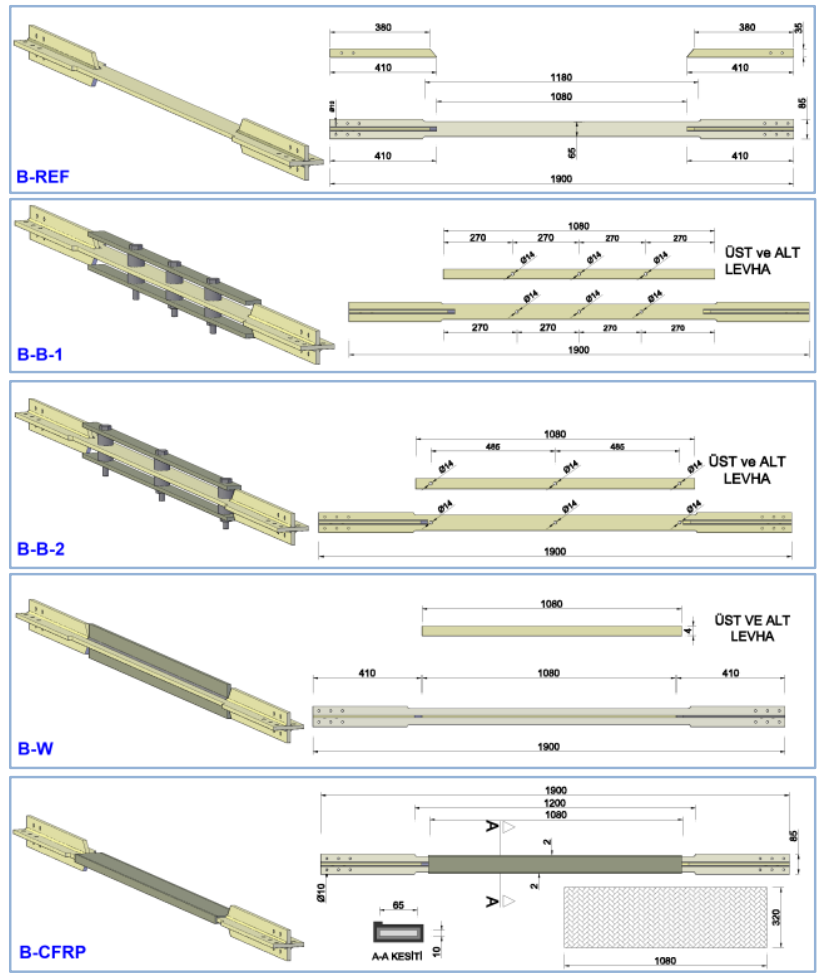

Şekil 4. Test edilen elemanların görünümü ve ölçüleri (ölçüler mm'dir)

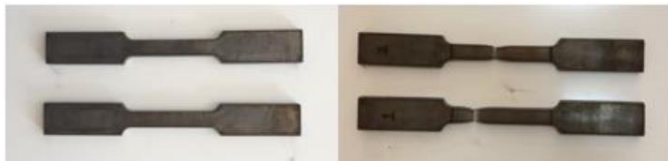

Şekil 5. Deney numunelerinin görünümü

(a) Deney öncesi ve (b) Deney sonrası

Tablo 2. Çelik malzemenin karakteristik özellikleri

\begin{tabular}{cccccc}
\hline Numune & Genişlik & Kalınlık & $\begin{array}{c}\text { Akma } \\
\text { Dayanımı } \\
\boldsymbol{f}_{\mathbf{y}}\end{array}$ & $\begin{array}{c}\text { Çekme } \\
\text { Dayanımı } \\
\boldsymbol{f}_{\mathbf{u}}\end{array}$ & Uzama \\
\cline { 2 - 6 } & $(\mathrm{mm})$ & $(\mathrm{mm})$ & $(\mathrm{MPa})$ & $(\mathrm{MPa})$ & $\%$ \\
\hline No 1 & 9.7 & 21.4 & 660 & 708 & 16.2 \\
No 2 & 9.7 & 20.9 & 647 & 702 & 16.5 \\
\hline
\end{tabular}

\subsubsection{CFRP malzemesi ve uygulamast}

Karbon takviyeli güçlendirme için tek yönlü CFRP malzemesi kullanılmıştır. CFPR malzemesi her yüzeyde 2 kat olacak şekilde $20 \mathrm{~mm}$ lik bindirme boyu hesaba katılarak çubuk gövdesi boyunca sarılması için $1080 \times 320 \mathrm{~mm}$ lik CFRP parçası kesilerek yapıştırma işlemine hazır hale getirilmiştir. Astar ve yapıştırma malzemeleri Mape-Wrap markadır. Yapıştırılacak yüzeyin toz vb. maddelerinden arındırılması amacıyla üreticinin tavsiye ettiği şekilde hassas terazide tartım yapılarak epoksi astarı çubuk gövdesi boyunca uygulanarak kurumaya bırakılmıştır. Epoksi astarının kurumasından sonra epoksi uygulamasına geçilerek Mape Wrap 31 Comp A ve B karışım malzemelerinden toplam 75 gram epoksinin 32.5 gramı çubuk yüzeyine, kalanı ise CFRP malzemesinin üzerine yedirilmiştir. Aralarında hava boşluğu kalmayacak şekilde yüzeye baskı yapılarak, 
numune ve CFRP malzemesinin ilk yapışması sağlanmış ve ardından kurumaya bırakılmıştır. Daha sonra alt tarafın ilk katı için de 75 gram epoksi kullanılarak aynı işlemler uygulanmıştır. Son olarak tüm çubuğun ikinci katını uygulamak için hazırlanan 400 gr epoksi reçinesinin 200 gramı önce numune yüzeyine geri kalan kısmı 200 gram ise CFRP malzemesinin üzerine, aralarında hava boşluğu kalmayacak şekilde yapılmıştır. Bu haliyle 5 gün boyunca kurumaya bırakılmıştır.

\subsubsection{Bulon ve destek pullarl}

Esas çubuklar, bağlantı levhalarına, M10 çaplı 8.8. sınıfında bulonlarla bağlanmıştır. Bağlantı bulonlarının haricinde, bulonlu güçlendirme tasarımında üçer adet M14 8.8 sınıfinda bulon kullanılmıştır. Bulonlar güçlendirme levhaları arasında sabit bir mesafe sağlanması adına Şekil 6.'da gösterilen, ortalarından bulonların geçeceği çapta delik açılmış $40 \mathrm{~mm}$ çapında $30 \mathrm{~mm}$ boyunda pullar (silindirler) kullanılmıştır.

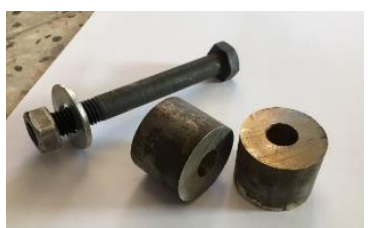

Şekil 6. Bulonlu güçlendirmede kullanılan parçalar

\subsection{Test düzeneği ve kullanılan cihazlar malzeme özellikleri}

Çelik çaprazlar ve basınç çubukları ile yapılan çalışmalarda üç farklı yükleme düzeneği kullanılmaktadır. Bunlardan birincisi test numunesinin düşey doğrultuda yerleştirildiği düzenek, ikincisi yatay konumda yerleştirildiği düzenek [21, 23], üçüncüsü ise çapraz eleman olarak başka bir kolon veya çerçeve sisteme bağlanan düzenektir [23]. Bu çalışmada seçilen deney düzeneği, basınç çubuklarının yatay konumda ve eksenel normal kuvvetle yüklenmesini sağlayacak şekilde düzenlenmiştir ve bu düzenek tek eksenli deney düzeneği olarak adlandırılmaktadır [23]. Sistemin her iki ucu ötelenmeyi önleyen rijit yükleme duvar ve rijit çelik destek kolonuna bağlanmaktadır. $\mathrm{Bu}$ sayede uygulanan kuvvet basınç çubuğuna etki ettirilmiş olup bütün deformasyonlar basınç çubuğunda gerçekleştirilmektedir. Deney düzeneğinin görünümü Şekil 7'de verilmiştir.

Eksenel yükleme hidrolik pistona bağlı manuel krikoyla yükleme hızı sabit tutularak (yaklaşı $1,5 \mathrm{kN} / \mathrm{sn}$ ) uygulanmıştır. Hidrolik krikonun ucunda $1000 \mathrm{kN}$ kapasiteli ve kalibrasyonlu yük hücresi montajlanmıştır. Yük değerleri bu cihaz yardımıyla elde edilmiştir. Test numunelerinin her içi ucu numuneler için özel üretilen çelik plakalarına 10'ar adet M10 8.8. sınıfı cıvata ile bağlıdır. Bağlantı plakaları da 6'şar adet M16 8.8. sınıfi bulonla çelik kolona ve yük hücresi bağlantı parçasına bağlıdır.

Deneylerde yük değerleri yük hücresiyle, yer değiştirme ölçümleri (boy uzama ve kısalması) ise deplasman ölçerler (LVDT- linear variable differential transformer) kullanılarak ölçülmüştür. LVDT deney düzeneğinde 3 adet kullanılmaktadır. Bunlardan ikisi numunenin doğu ve batısına yerleştirilmiştir. Toplam boy değişimini ölçebilecek şekilde montajlanan bu cihazlar, eksenel boy değişimini her iki yönden ölçmektedir. Üçüncü LVDT ise çıkış mesafesi ile boy kısalmasının kontrolü için piston çıkışına yerleştirilmiştir. Bunun yanı sıra, numune ortasının eksen dış1 yer değiştirme değerini (eksenden sapma) ölçmek adına, başka bir deplasman ölçer olan ipli potansiyometre (İP) kullanılmıştır. Çubuk üzerinde gerilme değişimlerini belirlemek amacıyla tek yönlü strain gaugeler (SG) yapıştırılarak gerinim değişimleri ölçülmeye çalışılmıştır.

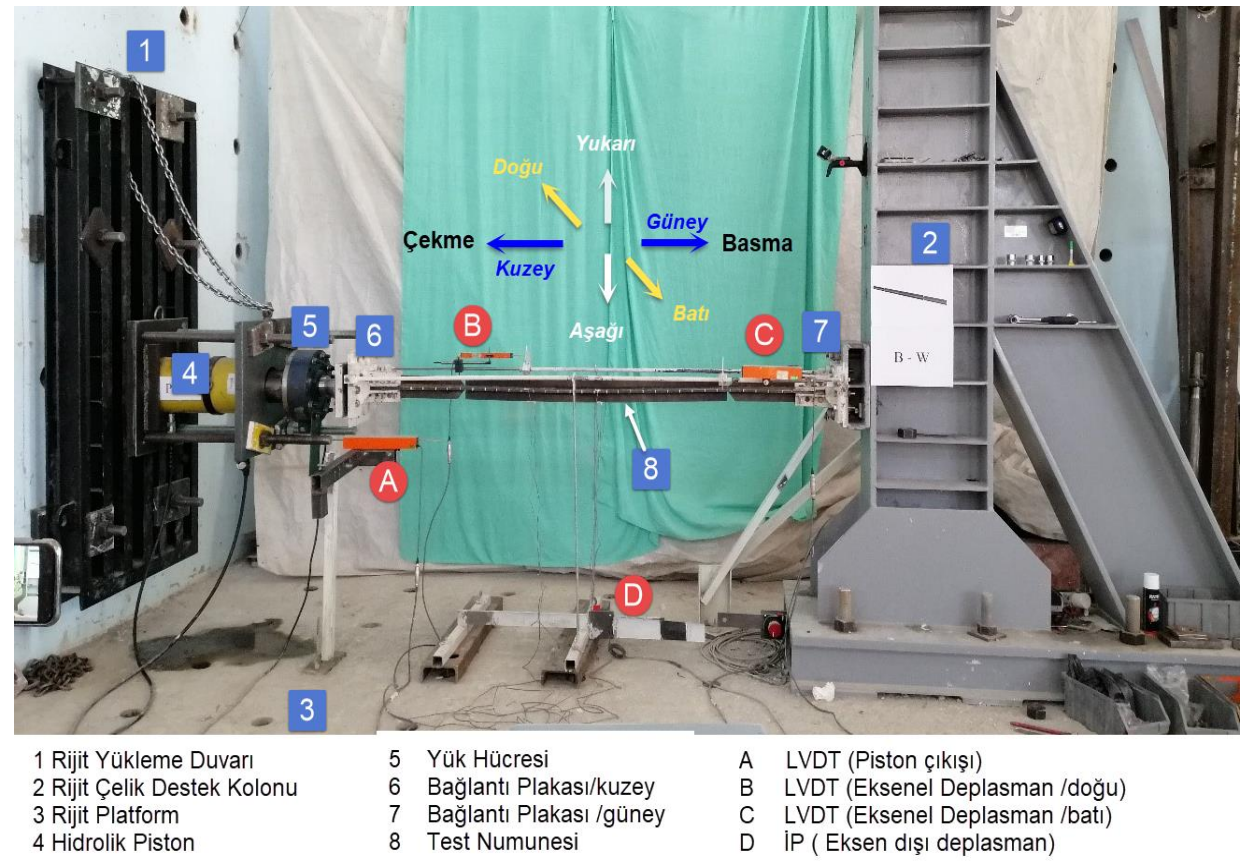

Şekil 7. Deney düzeneği 


\subsection{Test protokolü}

Yapısal eleman deneylerinde test numuneleri iki farklı şekilde yükleme prosedürüne tabi tutulabilir. Bunlardan ilki yük kontrollü yükleme, ikincisi yer değiştirme kontrollü yüklemedir. Her iki yükleme durumu için farklı ülkelerin ECCS (1986) [24], ATC-24 (1992) [25], FEMA-461 (2007) [26], JISF (2002) [27] ve ANSI/AISC 341-16 (2016) [21] gibi yönergeleri/şartnameleri bulunmaktadır. Bu çalışma kapsamında FEMA 461 kapsamında tavsiye edilen deplasman kontrollü yükleme prosedürü kullanılmıştır [5, 26].

FEMA 461 kapsamında Protocol I ve II olmak üzere iki farklı yükleme protokolü yer almaktadır. Bunlardan birincisi yar1-durağan yükleme testi (quasi-static loading test), ikincisi sarsma tablası testidir (shake table test). Protokol I kapsamında, yükleme geçmişleri tek yönlü (unidirectional) test, iki yönlü (bidirectional) test ve kuvvet kontrollü (force controlled) testi olmak üzere üç farklı yükleme prosedürü verilmektedir. Tek yönlü test, yalnız bir adet numune kullanılacaksa uygun bir döngüsel deneyin gerçekleştirilmesi amacıyla uygulanması gereken yükleme aşamalarını tarif etmektedir. Tek yönlü yüklemede referans değer olarak $\Delta_{\mathrm{m}}$ ve $\Delta_{0}$ değerlerinin hesaplanması gerekmektedir.

$\Delta_{0}=$ Yükleme geçmişinin hedeflenen en küçük deformasyon genliğidir (adımıdır). Bu değer ilk olarak gözlenen en düşük hasar durumundaki genlikten güvenli bir şekilde daha düşük olmalıdır. En düşük hasar durumuna kadar en az 6 döngü gerçekleştirilmiş olmalıdır. Eğer başlangıç hasarı için deformasyon genliği ile ilgili mevcut data bulunmuyorsa, tavsiye edilen $\Delta_{0}$ değeri 0.0015 civarındadır. ( $\Delta 0$, kat ötelenme indeksi bakımından $\delta / \mathrm{h}$ tır)

$\Delta_{\mathrm{m}}=$ Yükleme geçmişinin hedeflenen maksimum deformasyon genliğidir. $\mathrm{Bu}$ değer deneyden evvel hesaplanmalıdır. Bu değer esas deneyler öncesinde yapılacak monotonik deney yardımıyla hesaplanabilir. Ĕger hedeflenen değerden daha küçük bir ötelenmede en şiddetli hasar başlar ise, gerçek hasar başlangıç değerindeki kümülatif hasar etkisinin aslında numunenin tam yükleme geçmişinde gerçekleştiği ile karşılaştırılıp karşılaştırılamayacağını değerlendirmek için bir karar alınmalıdır. Eğer en şiddetli hasar durumu hedef değerde henüz ortaya çıkmamış ise yükleme geçmişi $0.3 \Delta$ kadar genlikte daha ileri artışlar kullanılarak devam ettirilmelidir. Önerilen bu genlik değeri monotonik deney sonuçları gibi kanıtların eksik olması durumunda 0.03'tür. (kat ötelenmesi bakımından, $\delta / \mathrm{h}),[5,26]$

Şekil 8.'de gösterildiği gibi yükleme geçmişi aşamalı artan deformasyon genliğinde tekrarlanan döngülerden oluşmaktadır. Her genlikte (adımda) 2 döngü yapılmalıdır. Uygulanacak yer değiştirme (veya ötelenme) büyüklüğü (genliği, adımı) yükleme başlangıcındaki a1 $=0.0048 \Delta_{\mathrm{m}}$ değerinden alınmalıdır. Başka bir deyişle $a_{i}$, döngü genliğini ifade edecek olursa, birinci genlik $\mathrm{a}_{1}, \Delta$ 'ya eşit (veya çok yakın bir değer), ve son planlanan genlik an, $\Delta_{\mathrm{m}}$ 'e eşit olmalıdır (veya çok yakın bir değerdedir). Tablo 3'de FEMA 461'de [26] verilen bağıl yükleme geçmişi yer değiştirme genlikleri verilmektedir. $a_{1}=0.0048 \Delta_{m}$ değeri için yük geçmişi grafiği Şekil 8'de verilmektedir.

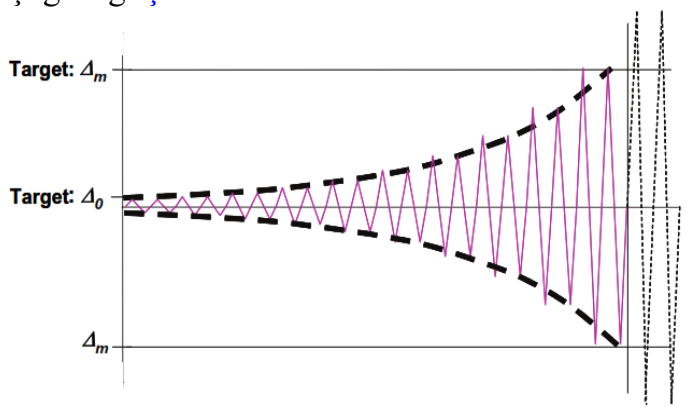

Şekil 8. Önerilen yükleme geçmişinin kavramsal diyagramı [26]

Tablo 3. Bağıl yükleme geçmişi yer değiştirme genlikleri (FEMA461 2007) [26]

\begin{tabular}{cccccccc}
\hline $\mathbf{n}$ & $\mathbf{1 3}$ & $\mathbf{1 2}$ & $\mathbf{1 1}$ & $\mathbf{1 0}$ & $\mathbf{9}$ & $\mathbf{8}$ & \\
\hline $\mathbf{a}_{\mathbf{i}} / \mathbf{a}_{\mathbf{n}}$ & 0.018 & 0.025 & 0.035 & 0.048 & 0.068 & 0.095 & \\
\hline $\mathbf{n}$ & $\mathbf{7}$ & $\mathbf{6}$ & $\mathbf{5}$ & $\mathbf{4}$ & $\mathbf{3}$ & $\mathbf{2}$ & $\mathbf{1}$ \\
\hline $\mathbf{a}_{\mathbf{i}} / \mathbf{a}_{\mathbf{n}}$ & 0.133 & 0.186 & 0.260 & 0.364 & 0.510 & 0.714 & 1.000 \\
\hline
\end{tabular}

Genlik artışı bir önceki genliğin 1,4 katı olacak şekilde yapılır. Bu şekilde yapılan yükleme durumunda yükleme geçmişindeki adım veya artış sayısını ifade eden döngü artış sayısını gösterir $\mathrm{n}$ değeri $>10$ olmalıdır. Her bir genlik değerinde 2 döngü yapılacağından toplam döngü sayısı en az 20 olmalidir.

$\mathrm{Bu}$ çalışmada monotonik deney yapılmayıp başlangıç akma değeri, çekme testi ile ölçülen çelik malzemesinin akma dayanımı dikkate alınarak belirlenmiştir. Belirlenen akma değeri ve akma uzaması değeri dikkate alınarak esas numunenin boyuna göre orantılanmış ve numune $\Delta_{0}$ akma genliği (akma uzaması) 1,51 mm bulunmuştur. 1,4 katı dikkate alınarak göçmeden en az 10 döngüyü içeren yükleme protokolü belirlenmiştir. Belirlenen yükleme protokolü Şekil 9'da verilmektedir.

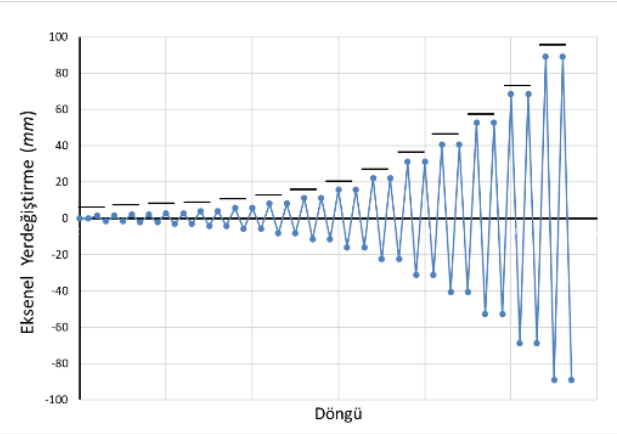

Şekil 9. Kullanılan yükleme protokolü

\section{Bulgular ve tartışma}

Önceki bölümde açıklanan test aparat1, cihazları ve ekipmanı kullanılarak, çubuk kuvvetleri, histeresis eğrileri, eksenel yük-eksenel yer değiştirme tepkileri, zarf eğrileri ve enerji süneklik oranları, her numune için ölçülen eksenel 
yük-eksenel yerdeğiştirme grafikleri kullanılarak belirlenmiştir. Güçlendirme yöntemlerinin yapısal katkı veya olumsuzlukları birbirleriyle karşılaştırılmıştır.

\subsection{Eksenel yük kapasiteleri}

Referans numune (B-REF) basınç yüklemesinde akma gerilmesine ulaşamadan burkulmuştur (Şekil 10). Bu durum sadece sonraki basınç yük kapasitesini değil, uzama ve kısalmaya bağlı, akma sonrası eksenel çekme kapasitesini de etkilemektedir. Sargılanmıș diğer numunelerin de tamamı basinç yüklemesinde burkulmuştur (Şekil 10). Ancak burkulma yerleri referans çubuğa göre farklılık göstermektedir. Burkulma sonrası davranış, ilk burkulma noktasındaki yorulmaya bağlı bazı numunelerde kopma ile sonuçlanmıştır. Numunelerin çekme ve basınç eksenel yük seviyeleri bu kuvvet değerlerinin yükleme seviyesi ve referans çubuğuna göre artan miktarları olan Tablo 4 'te verilmiştir. Çekme ve basınç bölgelerinde eksenel yük tepkilerinin değişiminin grafiksel gösterimi Şekil 11'de verilmiş̧ir. En yüksek değerler, çekmede yaklaşık aynı kalırken, basınç yüklemesinde en yüksek değere B-W numune ulaşmıştır. $\mathrm{Bu}$ numunenin çekme eksenel yük kapasitesinde de artış gözlenmiştir.

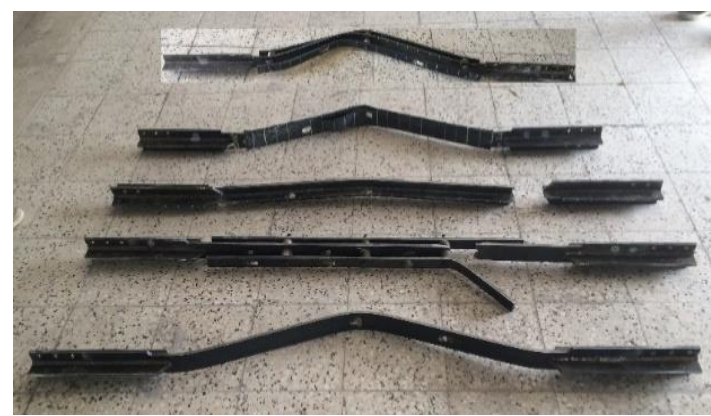

Şekil 10. Test sonrası numunelerin görünümleri

Tablo 4. Maksimum eksenel yük değerlerinin karşılaştırılması

\begin{tabular}{ccccc}
\hline \multirow{2}{*}{ Numune } & \multicolumn{2}{c}{ Çekme } & \multicolumn{2}{c}{ Basınç } \\
\cline { 2 - 5 } & $\begin{array}{c}\text { Maksimum } \\
\text { Eksenel } \\
\text { yük } \\
\mathrm{kN}\end{array}$ & $\begin{array}{c}\text { Referansa } \\
\text { göre } \\
\text { değişiim* } \\
\%\end{array}$ & $\begin{array}{c}\text { Maksimum } \\
\text { Eksenel yük }\end{array}$ & $\begin{array}{c}\text { Referansa } \\
\text { göre } \\
\text { değişim* } \\
\text { kN }\end{array}$ \\
\hline B-REF* & 235.50 & 0.0 & -31.69 & 0.0 \\
B-CFRP & 240.30 & 2.04 & -41.66 & 31.44 \\
B-W & 312.60 & 32.74 & -249.44 & 687.08 \\
B-B-1 & 228.44 & -3.00 & -92.49 & 191.85 \\
B-B-2 & 239.50 & 1.70 & -38.05 & 20.07 \\
\hline
\end{tabular}

\subsection{Histeresis e ğrileri}

Histeresis eğrileri, çevrimsel yükleme altındaki elemanların yapısal özelliklerini ortaya koymaktadır. Bu döngüsel davranış, özellikle basınca çalışan elemanlarda, burkulmadan yükün taşınmasına bağlı daha tutarlı bir davranışın ortaya çıkıp çıkmadığının gözlenmesine ve karşılaştırılmasına imkan sağlamaktadır. Histeresis eğrileri, akma noktasına kadar lineer ve lineer olmayan elastik bir bölgeden ve akma noktasından sonra plastik bir bölgeden oluşur. Elastik bölgedeki yükselen eğim ve plastik bölgedeki azalan eğim, elemanın mukavemetini, sünekliğini ve enerji yutma kapasitesini ortaya koyarak genel yapısal karakteristiğini ortaya çıkarmaktadır.

Çelik çaprazların eksenel yük altındaki sismik davranışını belirlemek için, yerdeğiştirme kontrollü yükleme protokolüyle eksenel kuvvet-eksenel yer değiştirme değerleri elde edilmiş ve bu değerler kullanılarak histerezis eğrileri oluşturulmuştur. Bu eğriler her bir numune için ayrı ayr1 Şekil 12'de sunulmuştur.

\subsection{Zarf ĕgrileri}

Histeresis eğrileri kullanılarak zarf eğrileri elde edilmiştir. Zarf eğrileri güçlendirilmiş çelik çapraz elemanların maksimum yük kapasitelerini ve sünekliklerinin daha net bir biçimde tanımlanmasına olanak sağlar ve bu parametreleri belirlemek amacıyla kullanılır. Bu eğriler, her bir numunenin histeresis eğrileri üzerinde hedef yerdeğiştirmedeki pik yük değerlerinin birleştirilmesiyle oluşturulmuştur (bkz. Şekil 12). Numuneleri birbirleriyle karşılaştırmak amacıyla aynı grafik üzerinde Şekil 13'te verilmiştir.

Zarf eğrileri oluşturulurken çekme ve basınç bölgelerindeki döngülerde, hedef yer değiştirme değerine karşıllk gelen eksenel yük değerleri esas alınmıştır. Maksimum yüke ulaşan eğrinin dönüşte akma yükü değerine karşlık geldiği yerdeğiştirme değeri, $\Delta_{\mathrm{u}}$ değeri olarak belirlenir. Bir sonraki çevrimde akma yükünden çok düşük değerlere ulaşırsa bir önceki çevrimin maksimum değeri $\Delta_{\mathrm{u}}$ değeri olarak alınır. Yük ve gerilme değerleri ikinci çevrimde azalır. Bunun nedeni çubuklarda oluşan plastik mafsal ve malzemede gelişen yorulmadır.

\subsection{Süneklik ve enerji sünekliği}

Süneklik ve enerji sönümleme kapasitesi, sismik tasarımda dikkate alınması gereken temel parametrelerdir. Yapı sünekliği, o yapıyı oluşturan elemanların sünekliği ile doğrudan ilişkilidir [28]. Bir yapının veya yapısal elemanların sünekliğini tanımlamanın birçok yolu vardır. Bunlardan biri, maksimum yerdeğiştirme değerinin $\left(\Delta_{\mathrm{u}}\right)$, akma veya yerel burkulmanın meydana geldiği yerdeğiştirme değerine $\left(\Delta_{y}\right)$ oranı olarak Denklem (1)'de ifade gibi tanımlanmaktadır [29]. Şekil 14'de şekilsel gösterimine bağlı hesaplanan süneklik oranları Tablo 5'de verilmiştir.

$$
\mu=\frac{\Delta_{u}}{\Delta_{y}}
$$

Tablo 5. Süneklik değerleri

\begin{tabular}{lcc}
\hline \multirow{2}{*}{ Numune } & \multicolumn{2}{c}{ Sünekliği Oranı $\mu$} \\
\cline { 2 - 3 } & Çekme & Basınç \\
\hline B-REF & & 2.01 \\
B-B-1 & 34.96 & \\
B-B-2 & 34.96 & 2.33 \\
B-CFRP & 34.96 & 2.94 \\
B-W & 12.02 & 2.02 \\
\hline
\end{tabular}




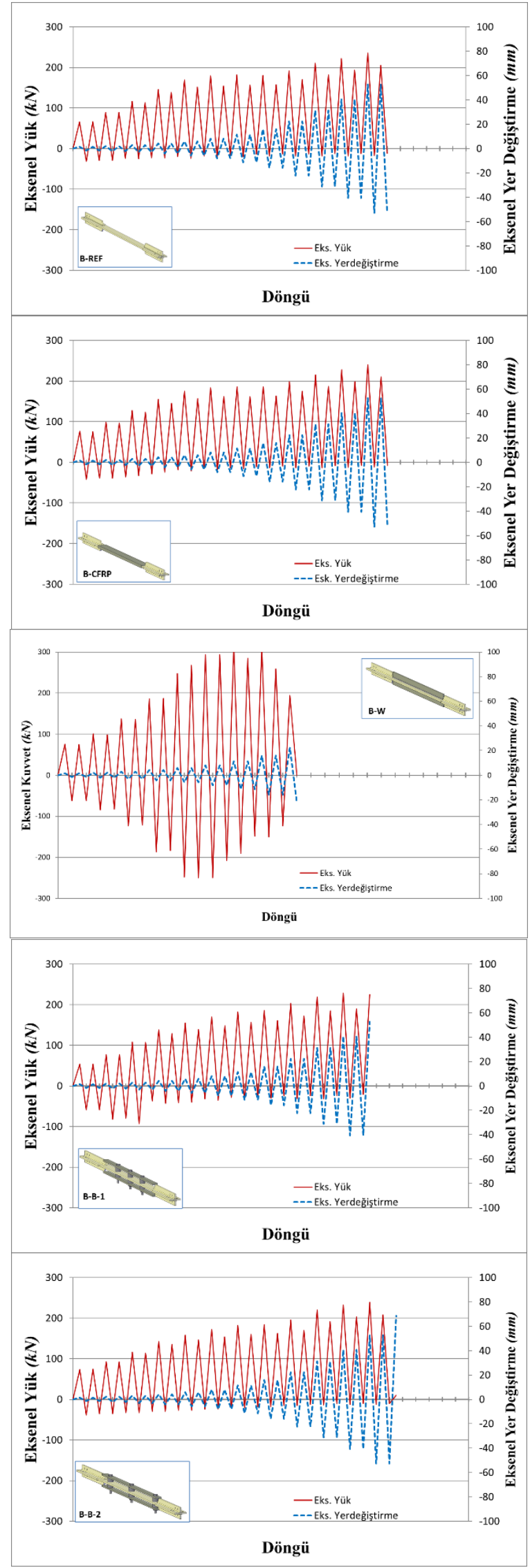

Şekil 11. Eksenel yük tepkilerinin değişimi
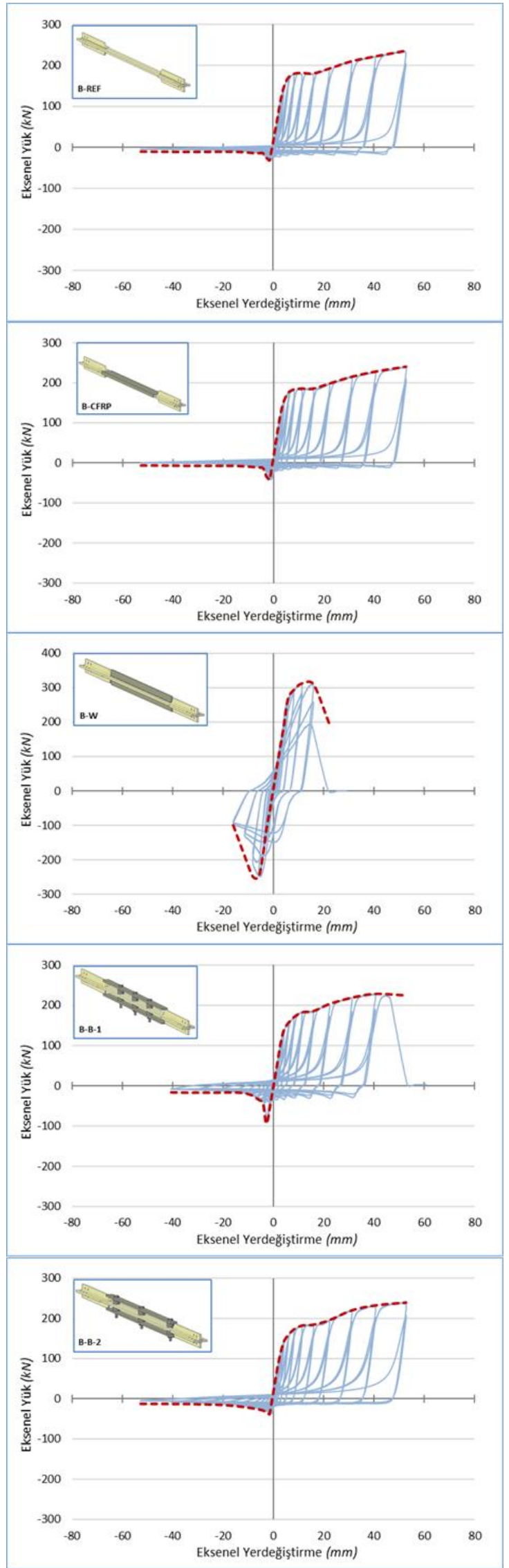

Şekil 12. Numunelerin histeresis ve zarf eğrileri 


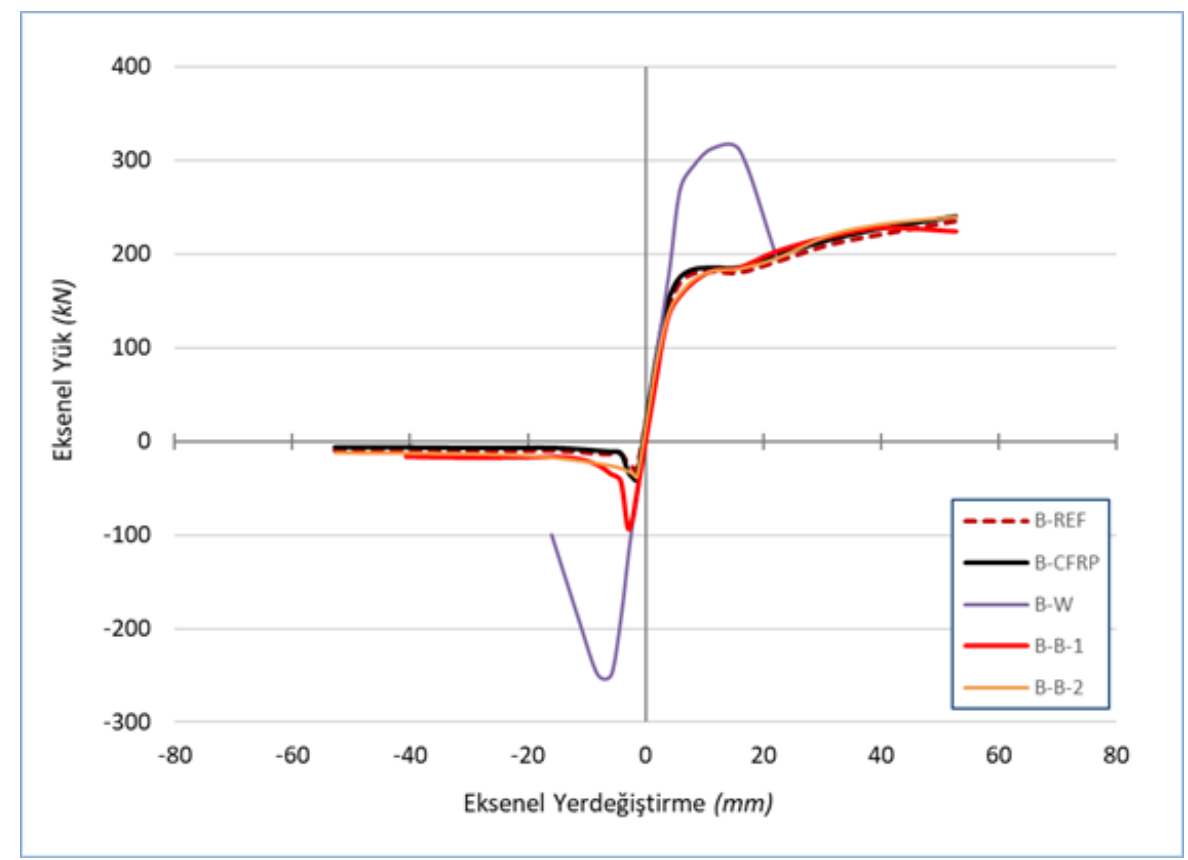

Şekil 13. Zarf eğrilerinin karşılaştırılması

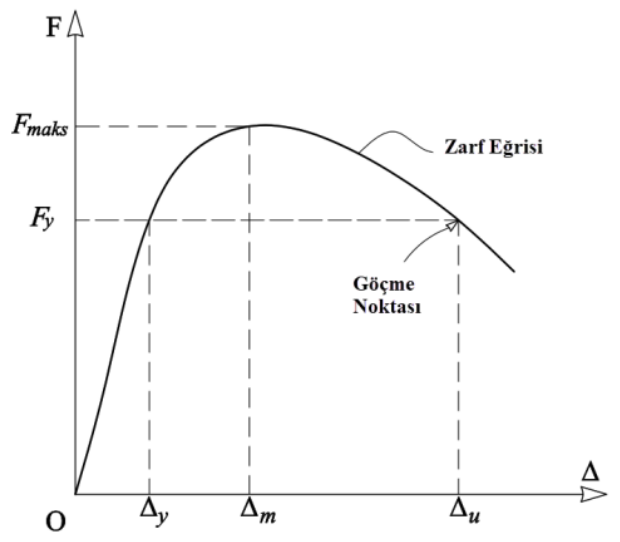

Şekil 14. Göçme noktasının ve süneklik parametlerinin belirlenmesi [29]

Süneklik ifadesi, başka bir deyişle yerdeğiştirme oranı şeklinde de tanımlanabilir. Başka bir deyişle, maksimum yerdeğiştirme $\left(\Delta_{u}\right)$ ile akma yerdeğiştirmesi $\left(\Delta_{y}\right)$ farkının yine akma yerdeğiştirmesine oranı olarak da tanımlanabilir. $\mathrm{Bu}$ durumda süneklik oranın Denklem (2)'deki gibi hesaplanır. Buradaki $\mu_{1}$ değeri, basınç çubuğunun, eleman süneklik oranını gösterir.

$$
\mu_{1}=\frac{\Delta_{u}-\Delta_{y}}{\Delta_{y}}
$$

Akma yer değiştirmesi ve nihai yer değiştirme oranının hesaplanmasından farklı olarak, enerji yutma kapasitelerine bağlı olarak süneklik oranlarının belirlenmesi de mümkündür. $\mathrm{Bu}$ şekilde hesaplanan süneklik değerleri numuneler arasındaki fark1 daha net ortaya koymaktadır. Deney numunelerine yerdeğiştirme kontrollü yükleme protokolü uygulandığından ve yükleme protokolündeki hedef yer değiştirme değerleri her numune için aynı olduğundan, eksenel yer değiştirmelere göre süneklik oranlarının belirlendiği değerler arasında benzerlikler oluşmaktadır. Başka bir deyişle direkt olarak süneklik hesaplanması, yerdeğiştirme kontrollü deneylerde karşılaştırmayı zorlaştırmaktadır. Aradaki farkı gösterecek hesaplama yapılmalıdır ki bu farkı oluşturacak parametre ise eksenel yük seviyesidir.

Deneylerde aynı eksenel yer değiştirme değerlerine kıyasla farklı eksenel yük değerlerine sahip histeresis eğrilerinde görülmektedir. Diğer bir deyişle, hedef yerdeğiştirmelerde yük değerleri değişir. $\mathrm{Bu}$ nedenle numuneler nihai taşıma kapasite değerlerine ulaşana kadar enerji kayıp değerleri dikkate alınarak süneklik oranlarının hesaplanması daha doğru bir yaklaşımdır. Bunun yapılması adına Şekil 14'deki hesaplama yaklaşımı ile elastik enerji kayıp değerleri, ardından Denklem (3) kullanılarak süneklik oranı hesaplanmaktadır.

$$
\mu_{E}=\frac{E_{p}-E_{y}}{E_{y}}
$$

$\mathrm{Bu}$ denklemde $\mathrm{E}_{\mathrm{y}}$ elastik sınıra kadar kümülatif enerji tüketim değeri, $E_{p}$ ise plastik bölgedeki kümülatif enerji tüketim değeridir. Bu açıklamaya göre hesaplanan enerji süneklik oranları grafiksel olarak Şekil 15 'te ve hesap edilen değerler bakımından Tablo 6'da verilmiştir. Grafik ve tabloda basınç bölgesindeki enerji değerleri dikkate alınan değerlerdir. Çekme bölgesinde ise kopma veya yırtılma gerçekleşinceye kadar olan değerler dikkate alınmıştır. 


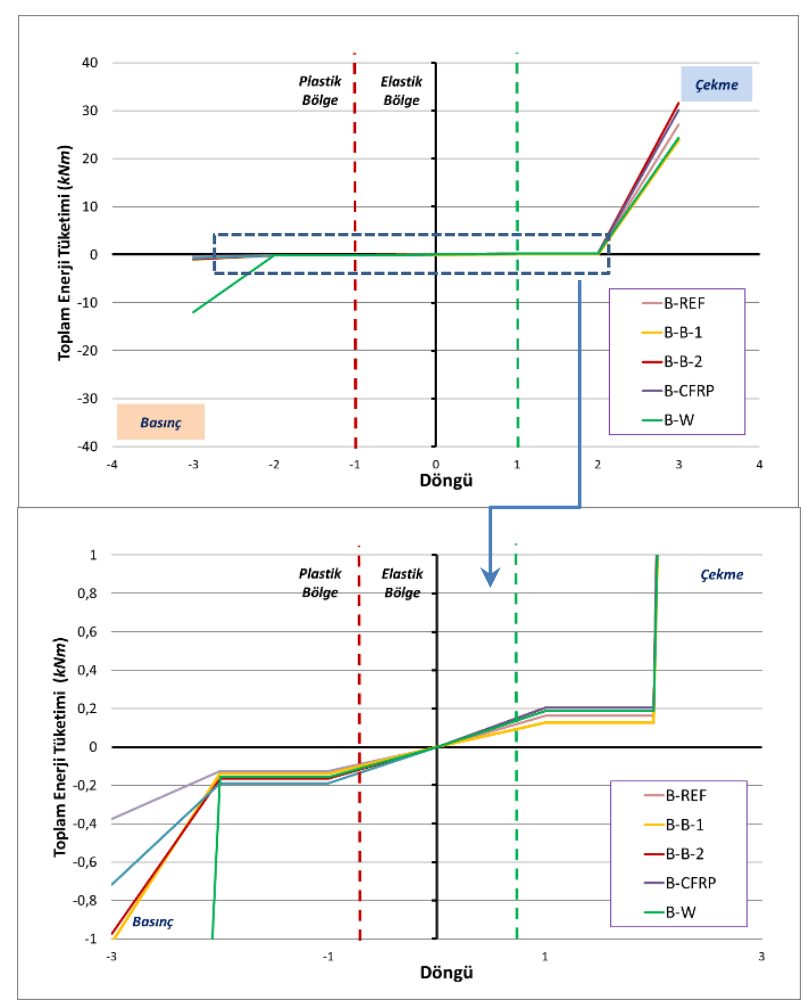

Şekil 15. Test numunelerinin taşıma kapasitelerini yitirinceye kadar olan elastik ve plastik enerji tüketimleri

Tablo 6. Enerji sünekliği değerleri

\begin{tabular}{lcc}
\hline \multicolumn{1}{c}{ Numune } & \multicolumn{2}{c}{$\begin{array}{c}\text { Enerji Sünekliği Oranı } \\
\mu_{E}=\mathrm{E}_{\mathrm{p}}-\mathrm{E}_{\mathrm{y}} / \mathrm{E}_{\mathrm{y}}\end{array}$} \\
\cline { 2 - 3 } & Çekme & Basınç \\
\hline B-REF & 168.04 & 3.00 \\
B-B-1 & 187.60 & 6.34 \\
B-B-2 & 154.38 & 4.93 \\
B-CFRP & 146.10 & 2.79 \\
B-W & 130.03 & 75.69 \\
\hline
\end{tabular}

Tablo 6'ya göre çekmede en yüksek enerji sünekliği BB-1 numunesinde görülmektedir. Enkesit alanı bulon deliği sebebiyle azalmış olsa da bağlanan levhaların katkı sağladığ anlaşılmaktadır. Basınç bölgesinde bulonlu sargıların bir miktar katkısı görülmüştür. Basınç bölgesinde ise en büyük enerji sünekliği $\mathrm{B}-\mathrm{W}$ numunesinde görülmüştür. $\mathrm{Bu}$ durum en yüksek basınç dayanımı gerilmesine ulaşması sonucudur. Ancak bu durum uzun sürmeyerek, ileri yerdeğiştirme mertebelerinde zayıf enkesitte plastik mafsal oluşmasına bağlı, çekmede erken kopmayla sonuçlanmıştır.

\subsection{Enerji tüketim değerleri}

Histerisis eğrisinin altında kalan alanlar çekme ve basınç döngülerinden hesaplanarak enerji tüketim değerleri elde edilmiştir. Çekme ve basınç yüklemesinden, her bir adım için ayrı ayrı hesaplanan değerler sonrasında, bir önceki enerji tüketimi değeriyle hesaplanarak kümülatif (birikimli) enerji tüketim değerlerine ulaşılmıştır. Test numunelerine ait kümülatif enerji tüketimi grafikleri, çekme ve basınç döngüleri için ayrı ayrı Şekil 16 ve Şekil 17'de verilmektedir. Çekme enerjileri birbirine yakın seyrederken, erken döngülerde kopmasına rağmen, B-W numunesinin toplam enerji tüketimi, diğer numunelerin deplasman seviyesine göre düşük kalmasına rağmen yine diğer numuneler yakalamıştır. Ancak basınç bölgesinde B-W'nın enerji tüketimi diğerlerine göre çok daha fazladır. Basınç döngülerindeki bir sonraki yüksek değer B-B-1 numunesinde görülmektedir. Kümülatif enerji tüketimi değerleri enerji sünekliği ile paralellik göstermektedir.

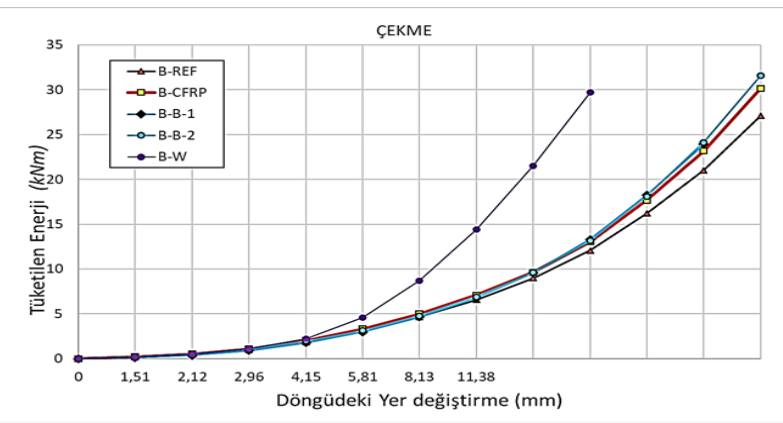

Şekil 16. Test numunelerinin kümülatif enerji grafiği (çekmede)

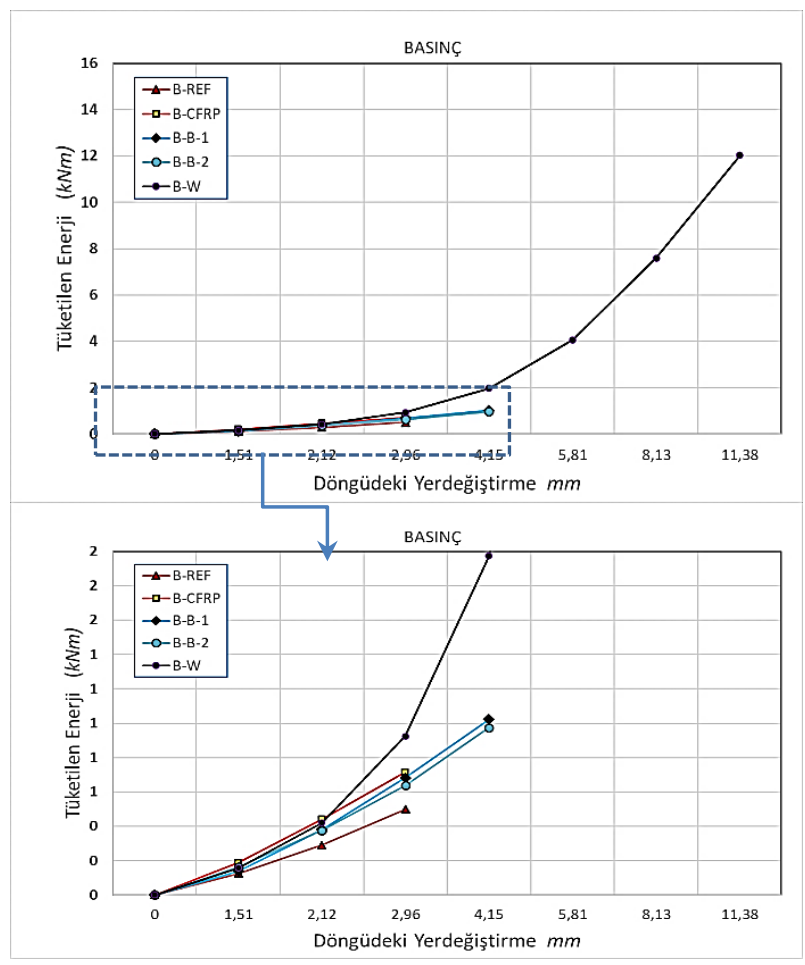

Şekil 17. Test numunelerinin kümülatif enerji grafiği (basınçta)

\subsection{Hasar mekanizmalarl}

Güçlendirme elemanlarının bağlantı şekli ve türü göçme mekanizmalarını doğrudan etkilemiştir. İleri seviyedeki hasar mekanizmalarının görülmesi adına taşıma gücü çok küçük mertebelere de ulaşsa da yüklemeye devam edilmiştir. Çubuklar üzerinde en çok gerilme yığılmasının olduğu noktalarda tersinir tekrarlı yüklere bağlı yorulma gerçekleşmiş ve kopmuştur. Hasar mekanizmaların her bir numune için hasar fotoğrafları ile birlikte aşağıda sunulmaktadır. 


\subsubsection{B-REF numunesi}

Referans numune, beklenildiği gibi, zayıf ekseninde akma gerilmesinin aşıldığı ilk adımda burkulmuştur. İlerleyen döngülerde eksen dışı yerdeğiştirmeye bağlı orta noktadaki plastik mafsalda yorulma gerçekleşmiş ve bu durum çekme kuvvetlerinde bir miktar düşüşe sebep olmuştur. B-REF numunesinin deney sonrası hasar görmüş hali Şekil 18'de verilmiştir.

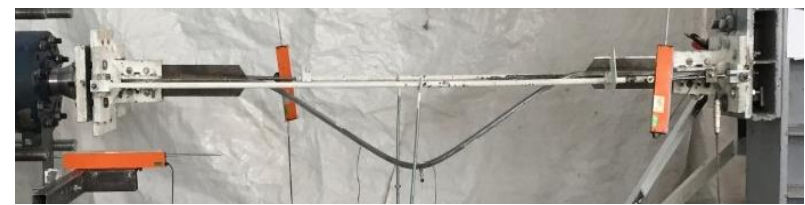

Şekil 18. B-REF numunesi test sonrası hasar görünümü

\subsubsection{B-CFRP numunesi}

CFRP sargılı numune referans numuneye benzer şekilde burkulmuştur. Öncelikle numune ortasının üst kuzey tarafındaki CFRP sargının (basınç bölgesindeki sargı) etkiyen basınç kuvvetiyle çelik levhadan ayrılmıştır. Bu zamana kadar dayanımda görülen artış, bu andan sonra düşmeye başlamış ve numunenin eksen dışı hareketi artış göstermiştir. Buna deformasyona bağlı uçlara yakın CFRP sargılarında da açılmalar oluşmuştur. B-CFRP numunesinin deney sonrası hasar görmüş hali Şekil 19'da verilmiştir.

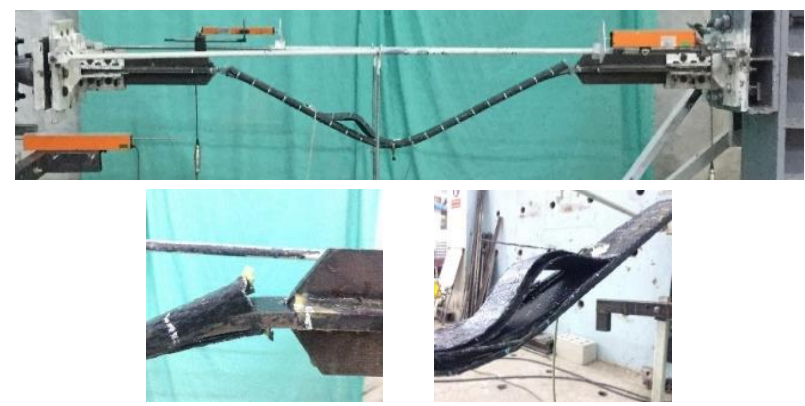

Şekil 19. B-CFRP numunesi test sonrası hasar görünümü

\subsubsection{B-W numunesi}

En yüksek basınç yüküne ulaşan B-W numunesi, levha eklenmemiş (zayıf kalan) güney taraftaki kesitinden, döngülerdeki yorulmaya bağlı kopmuştur. İlk burkulma yine bu kesitte meydan gelmiştir. B-W numunesinin deney sonrası hasar görmüş hali Şekil 20’de verilmiştir.

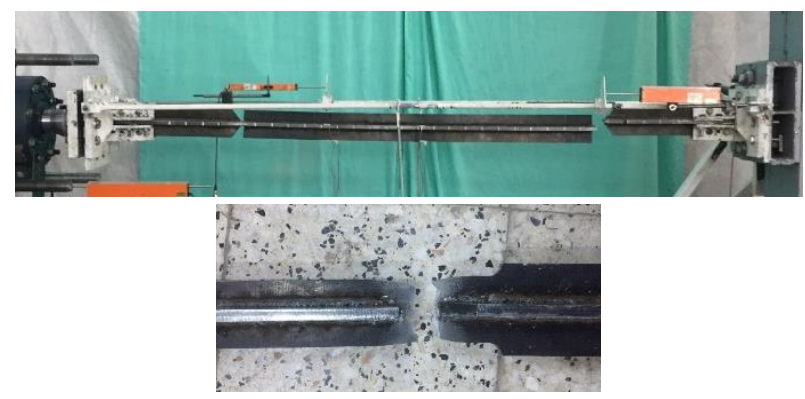

Şekil 20. B-W numunesi test sonrası hasar görünümü

\subsubsection{B-B-1 numunesi}

Bulonlu güçlendirmenin ilk numunesi olan B-B-1 numunesinde ilk burkulma güney ucundaki bulon bağlantısının olduğu noktada gerçekleşmiştir. Bulonlar arası mesafe ile kenar bulonların mesnete olan mesafeleri aynı, dolayısıyla burkulma boyları aynıdır. $\mathrm{Bu}$ numunede bulon çapına uygun dairesel bulon deliği açıldığı için bulon delikte bir miktar hareket etse de sonunda levhaya yaslanarak eksenel kuvvetin iletilmesini sağlamıştır. Enkesitin de delik sebebiyle zayıflamış bir enkesit olduğu için bu noktada burkulma gerçekleşmiştir. Eksen dişı yer değiştirmenin ilerlemesiyle birlikte üst güçlendirme levhası esas çubuğa yaslanmış ve serbest ucundan eğilmiștir. İlerleyen döngülerde ilk burkulmanın gerçekleştiği noktadan çekme döngüsünde kopmuştur. B-B-1 numunesinin deney sonrası hasar görmüş hali Şekil 21'de verilmiştir.
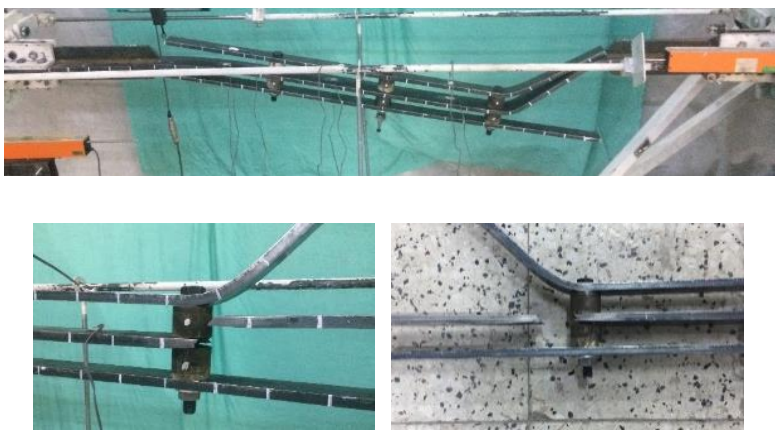

Şekil 21. B-B-1 numunesi test sonrası hasar görünümü

\subsubsection{B-B-2 numunesi}

İkinci bulonlu güçlendirme numunesi B-B-2'de burkulma orta noktaya yakın ve tüm levhaların eğilmesi şeklinde gerçekleşmiştir. Kenar bulonların mesnetlere yaklaştırılmasının ve kenar bulonlar için esas numunede açılan deliklerin kısa oval delik olarak açılmasının, bu davranışın gerçekleşmesinde etkili olduğu düşünülmektedir. Orta noktada ise oval delik bulunmadığı için esas çubuğundan gelen yanal yer değiştirme kuvveti güçlendirme elemanlarına daha uygun bir biçimde iletilmiş güçlendirme levhalarına aktarılmıștır. İlerleyen döngülerde kopma gerçekleşmemiş ancak bulon deliklerinin açıldığı zayıf enkesitte daralma gerçekleşmiştir. B-B-2 numunesinin deney sonrası hasar görmüş hali Şekil 22'de verilmiştir.
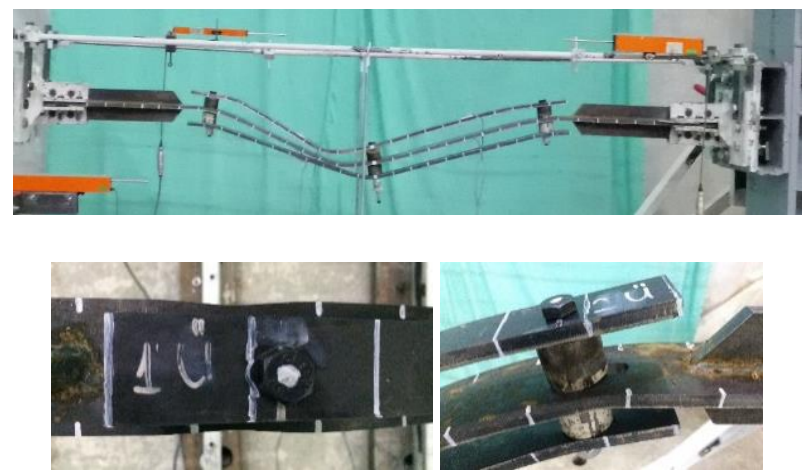

Şekil 22. B-B-2 numunesi test sonrası hasar görünümü 


\section{Sonuçlar}

$\mathrm{Bu}$ çalışma, mevcut üretimli çelik yapılardaki basınç çubuklarının eksenel basınç kapasitelerinin sonrada yapılan güçlendirmelerle artırılmasına yönelik yapılmışıtır. $\mathrm{Bu}$ kapsamda referans bir basınç çubuğuna dört çeşit güçlendirme uygulanarak tersinir tekrarlı eksenel yükler uygulanarak yapısal performansları incelenmiş̦ir. Uygulanan güçlendirmelerin üçü çelik takviyesi ile güçlendirme diğeri karbon elyaflı güçlendirmedir. Çelik güçlendirmelerin biri çubuğa levha kaynaklanmasıyla yapılırken diğer ikisi bulon bağlantılı güçlendirmeler olmuştur.

Elde edilen bulgulara göre aşağıdaki sonuçlara ulaşılmıştır.

- En yüksek basınç dayanımını kaynaklı güçlendirme olan B-W numunesi göstermiştir.

- $\quad$ B-W numunesi çekme dayanımında da en yüksek değere ulaşmış numunedir. Çünkü kesitin kaynakla takviye edilmesi sonucunda çekme yükünde de artış gözlenmiş̧ir. Buna karşın çubuğun her ki ucunda da gövde kesitine göre zayıf kalan enkesiti çubuğun erken kopmasına sebep olmuştur.

- Basınç kuvveti dayanımındaki artış diğer numuneler arasında B-B-1 numunesinde görülmüştür.

- Diğer bulonlu numune B-B-2 en düşük performanslı numune olmuştur. Ancak bulonlu güçlendirmelerde dayanım artışı düşük mertebelerde kalsa da bulonlu bağlantıların geometrik ve bağlantı yerlerinde yapılacak değişikliklerle geliştirilebileceği anlaşılmaktadır.

- Bulonlu bağlantılarda esas çubukta açılan bağlantı deliği kesit daralmasına sebebiyet verdiği için çekme döngülerinde erken göçmeye sebebiyet verebilmektedir.

- Karbon elyaf sargilı numune (B-CFRP) beklenildiği gibi yüksek basınç dayanımı gösterememiş̧tir. Uygulama aşamasında esas çubuğun daha pürüzlü hale getirilmesinin davranışı etkileyebileceği sonucuna varılmıştır. Bunun yanı sıra esas çubuğun enkesit geometrisinin farklı olması durumunda yapısal davranışı artırabileceği düşünülmektedir.

\section{Teşekkür}

Deneysel çalışmalarda yardımlarını esirgemeyen eski öğrencim ve sevgili kardeşim İnş. Müh. Ali Kemal Düğenci ile yine eski öğrencim İnş. Müh. Alperen Ahmet Baltaş'a teşekkür ederim.

\section{Çıkar çatışması}

Yazarlar çıkar çatışması olmadığını beyan etmektedir.

\section{Benzerlik oranı (Turnitin): $\% 5$}

\section{Kaynaklar}

[1] N. Hoveidae, and B. Rafezy, Overall buckling behavior of all-steel buckling restrained braces. Journal of Constructional Steel Research, 79, 151-158, 2013.https://doi.org/10.1016/j.jcsr.2012.07.022

[2] Q. Xie, State of the art of buckling-restrained braces in Asia. Journal of Constructional Steel Research, 61(6),
727-748, 2005. https://doi.org/10.1016/j.jcsr.2004. 11.005 .

[3] D. MacEachern and P. Sadeghian, Hybrid FRP strengthening of slender steel members for buckling control. Journal of Composites for Construction, 24(5), 04020039, 2020. https://doi.org/10.1061/(ASCE)CC. 1943-5614.0001050.

[4] T. Yazan, Merkezi güçlendirilmiş çerçevelerde sürtünmesiz çelik basınç çubukları. Türkiye Mühendislik Haberleri Dergisi, 436: 47-52. 2005

[5] O. Düğenci, Artı kesitli çekirdeğe sahip burkulması önlenmiş basınç çubuklarının eksenel yük altında deneysel ve numerik araştırılması, Doktora Tezi, Erciyes Üniversitesi Fen Bilimleri Enstitüsü, Türkiye, 2015.

[6] C. J. Black, N. Makris, and I. D. Aiken, Component testing, seismic evaluation and characterization of buckling-restrained braces. Journal of Structural Engineering, 130 (6): 880-894.2004. https://doi.org/ 10.1061/(ASCE)0733-9445(2004)130:6(880).

[7] T. Yoshino, and Y. Karino, Experimental study on shear wall with braces: Part 2. In Summaries of technical papers of annual meeting, Architectural Institute of Japan, 11, 403-404, 1971.

[8] M. Wakabayashi, T. Nakamura, A. Katagihara, H. Yogoyama and T. Morisono, Experimental study on the elastoplastic behavior of braces enclosed by precast concrete panels under horizontal cyclic loading-Parts $1 \& 2$. In Summaries of technical papers of annual meeting, Architectural Institute of Japan, 10, 10411044, 1973.

[9] TÇYY-2016, Çelik Yapıların Tasarım, Hesap Ve Yapım Esaslarına Dair Yönetmelik. 4 Şubat 2016 tarih ve 29614 sayılı Resmi Gazete. 2016

[10] TBDY-2018, Türkiye Bina Deprem Yönetmeliği. 18 Mart 2018 Tarih ve 30364 Sayılı Resmi Gazete, 2018

[11] EN 1993-1-1:2005, Eurocode 3: Design of steel structures - Part 1-1: General rules and rules for buildings.

[12] TS EN 1993-1-1. Çelik Yapıların Tasarımı - Bölüm 11: Genel kurallar ve binalara uygulanacak kurallar (Eurocode 3). Türk Standartları Enstitüsü, 101s, Ocak 2014

[13] ANSI/AISC 360-16, Specification for Structural Steel Buildings, American Institute of Steel Construction, Inc. 680 pp. 2016.

[14] S. Naimi and S. Kaya, Betonarme yapıların çelik çapraz elemanlar ile güçlendirilmesi. AURUM Journal of Engineering Systems and Architecture, 3(2), 191-204, Feb. 2020.

[15] M. Elchalakani and D. Fernando, Plastic mechanism analysis of unstiffened steel I-section beams strengthened with CFRP under 3-point bending. Thinwalled structures, 53, 58-71, 2012.https://doi.org/ 10.1016/j.tws.2012.01.005.

[16] M. Elchalakani, A. Karrech, H. Basarir, X. L. Zhao, S. Fawzia, and M.F. Hassanein, Strengthening of mild steel struts using CFRP sheets subjected to uniform 
axial compression. Thin-Walled Structures, 116, 96112, 2017.https://doi.org/10.1016/j.tws.2017.03.010.

[17] X.Y. Gao, T. Balendra, and C. G. Koh, Buckling strength of slender circular tubular steel braces strengthened by CFRP. Engineering Structures, 46, 547-556, 2013. https://doi.org/10.1016/ j.engstruct.2012.08.010.

[18] G.L. Kulak, G.Y. Grondin, P.F. Adams, H.A. Krentz, Limit states design in structural steel. In:7th Canadian institute of steel construction, Alliston, Ontario; 2002.

[19] M. Vild and M. Bajer. Strengthening under load: numerical study of flexural buckling of columns. Procedia engineering, 190, 118-125, 2017.https://doi.org/10.1016/j.proeng.2017.05.316.

[20] TS EN ISO 6892-1,. Metalik Malzemeler-Çekme Deneyi, Bölüm 1: Oda Sicaklığında Deney Metodu. Türk Standartları Enstitüsü, 57 s, 2011

[21] ANSI/AISC 341-16, Seismic provision for structural steel building, American Institute of Steel Construction, Inc. 480 pp,2016.

[22] E. Ekiz and S. El-Tawil, Using CFRP to achieve buckling restrained behavior in steel compression members. In Structural Engineering Research Frontiers 1-11., 2007. https://doi.org/ 10.1061/40944(249)51.

[23] J. Park, J. Lee and J. Kim, Cyclic test of buckling restrained braces composed of square steel rods and steel tube, Steel and Composite Structures, 13 (5), 423 436, 2012 https://doi.org/10.12989/scs.2012.13.5.423

[24] ECCS, ECCS Technical Committee 1 - Structural Safety and Loadings - Technical Working Group 1.3 Seismic Design Recommended Testing Procedure for Assessing the Behaviour of Structural Steel Elements under Cyclic Loads. 1st Edition, Brussels, 1986.

[25] ATC-24, Guidelines for Cyclic Seismic Testing of Components of Steel Structures for Buildings, Report No. ATC-24, Applied Technology Council, Redwood City, CA, 1992.

[26] FEMA, Interim Protocols for Determining Seismic Performance Characteristics of Structural and Nonstructural Components Through Laboratory Testing, FEMA 461 Draft document, Federal Emergency Management Agency, 2007

[27] Building Research Institute, Japan Iron and Steel Federation,. Testing methods of the evaluation of structural performance for the steel structures, Japan, 2002

[28] Y. Fukumoto and G. C. Lee, Stability and ductility of steel structures under cyclic loading CRC press, 3, 1991.

[29] T. Usami, Y. Imai, T. Aoki and Y. Itoh, An experimental study on the strength and ductility of steel compression members under cyclic loading. Journal of Structural Engineering, 37, 93-106, 1991. 